\title{
The effects of aquaculture activities on species composition and diversity of native freshwater fish populations
}

\author{
Selin Ertürk Gürkan* and Şükran Yalçin Özdilek \\ Çanakkale Onsekiz Mart University, Faculty of Science and Arts, Department of Biology, Terzioglu Campus, 17100 Çanakkale, Turkey
}

Received 20 November 2017 / Accepted 23 March 2018

Handling Editor: Pauline Kamermans

\begin{abstract}
The rapid development of the aquaculture industry in recent years and the increase in the intensity of production has raised questions regarding potential environmental impacts. Understanding intra- and interspecific relationships between native and cultured species is important for sustainable use of natural resources. This study investigated the spatial and temporal effects of a fish farm constructed next to a river on the relative abundance and diversity of natural fish populations. Sampling was conducted at three stations, upstream and down stream from a trout farm and at a control site, on Kocabas stream in Çanakkale (Turkey) monthly between August 2015 and July 2016. There was no significant difference among the three stations in fish diversity. However, a remarkable seasonal and spatial variation in the composition and relative proportion of the indigenous fish assemblage were observed among the three stations. In conclusion, the fish farm might have influenced species composition and relative abundances particularly at the downstream station.
\end{abstract}

Keywords: Fish farm / aquatic ecology / stream ecology / fish assemblages / Kocabas Stream

\section{Introduction}

Freshwater ecosystems contain stream coastal systems, surface-underground waters and the ecotones between them (Ward and Tockner, 2001). Species diversity is shaped by ecological and evolutionary factors such as evolutionary speed, interspecific interactions, geographic region, environmental energy, productivity and environmental damage (Currie, 1991; Willig et al., 2003; Krebs, 2009) and also physicochemical conditions such as salinity, temperature, light, dissolved gases and nutrients (Geist, 2011). In freshwater habitats fishes are generally the most abundant group within vertebrates. Freshwater fish tend to be isolated by geology or behavior, which in evolutionary times leads to different populations and subspecies. Other factors affecting this process are also derived from the evolutionary history of the individual taxonomy and the distribution of geographical factors such as mountains and rivers (Allan and Flecker, 1993).

Factors threatening river diversity can be grouped under five headings: water quality, overexploitation, flow alterations, habitat degradation and introduced alien species (Allan and Flecker, 1993; Naiman and Turner, 2000; Malmquist and

*Corresponding author: serturk@comu.edu.tr
Rundle, 2002; Postel et al., 2003; Dudgeon et al., 2006; Geist, 2011). In addition, anthropogenic activities (dam construction, land use change and also aquaculture) may have negative impacts on diversity (Geist, 2011). During recent years, aquaculture production has advanced concerning water quality, disease control, and enriched feed, and generated stock improvements by selective breeding, hybridization, and molecular genetic technologies (Stickney, 1994). Even if aquaculture has several positive effects on diversity, the negative effects are debated, for instance escaped fish. Cultured species introduced to the wild may cause environmental or genetic hazards (Stokstad, 2002; Maury-Brachet et al., 2008). They may have detrimental impacts such as disease and parasite transmission to the wild (Beveridge, 1990) or habitat invasion (Diana, 2009). Ecological effects can also occur with increasing predation pressure on native fauna depending on escaped fish abundance (Goldberg et al., 2001). Other adverse ecological effects may occur, including organic pollution, eutrophication, nutrient enrichment and waste contamination. In addition to these impacts, algal blooms, oxygen insufficiency, decrease in water quality and habitat damage may arise as a result of chemical pollution (Boesch et al., 2001; Aubin, 2006; Miranda et al., 2016).The output resulting from aquaculture activities is primarily suspended solid matter composed of uneaten food and feces (Holmer, 


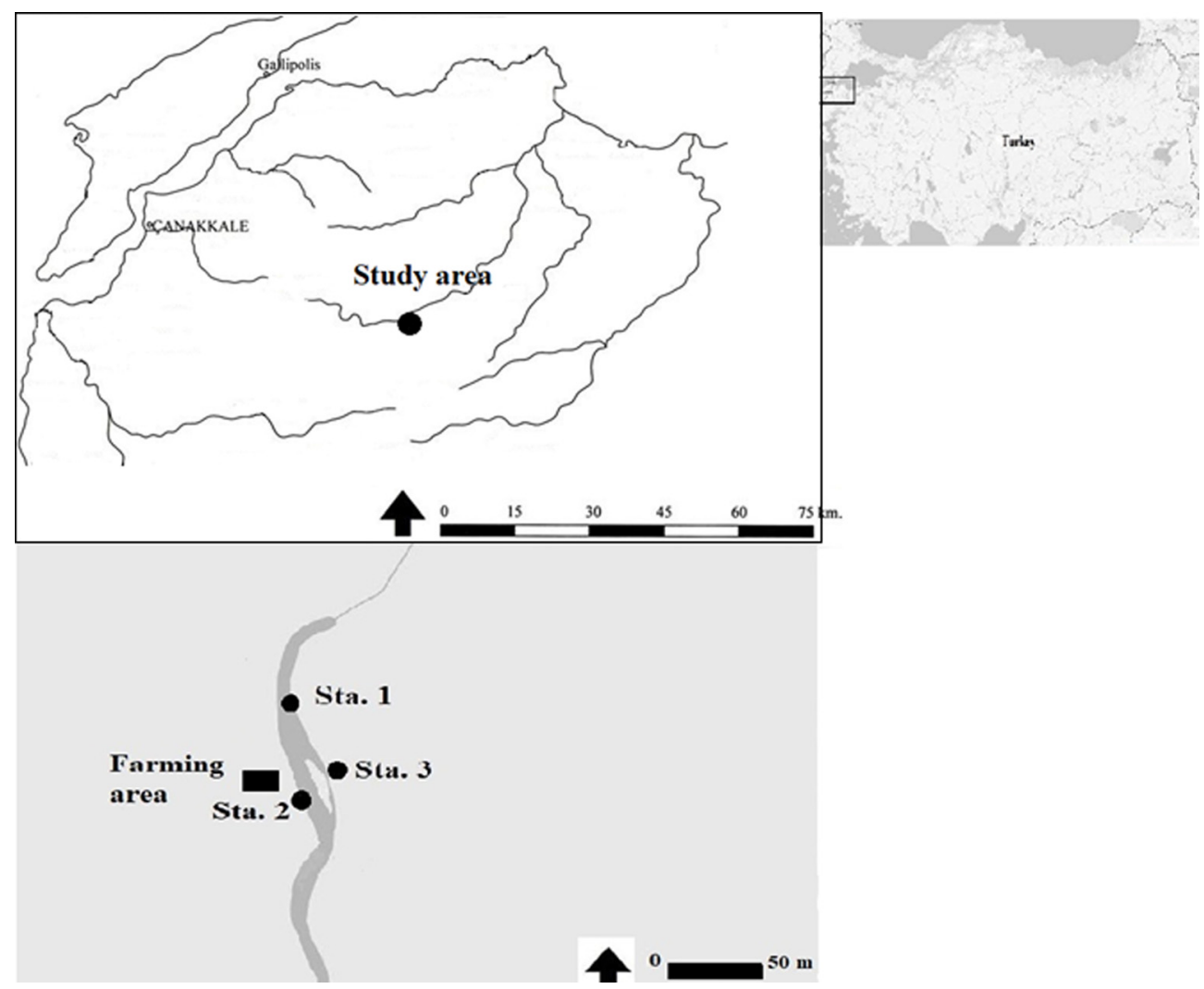

Fig 1. The study area with the three sampling stations. Flow direction is from station 1 to station 2 .

1991; Iwama, 1991) which is considered to cause damage to the natural environment (Troell and Norberg, 1998; Naylor et al., 2000). Many studies have shown how the products of fish farms affected negatively sediment chemistry and community dynamics of benthic fauna (Holmer, 1991; Findlay and Watling, 1997; Hargrave et al., 1997; Pergent et al., 1999; Pearson and Black, 2000; La Rosa et al., 2001; Mirto et al., 2002) but also the phytoplankton community (Miranda et al., 2016). Studies on the ecological effects of aquaculture activities have generally focused on water quality and benthic composition (Demir et al., 2001; Wilding et al., 2012). Demir et al. (2001) investigated the effect of a O. mykiss farm on the dam reservoir on plankton and benthos abundance. Among the stations identified, higher phytoplankton, zooplankton and benthos abundance was found at stations closest to the aquaculture unit. Wilding et al. (2012) examined the effect of trout farms on macrobenthos with a camera system. At the end of the study, solid wastes were determined by a benthic flux model, which showed that macrobenthic organisms near the farm were negatively affected. There are some studies on the effects of aquaculture activities on biodiversity and abundance, particularly in marine areas (Carss 1990; Dempster et al., 2002, 2004; Machias et al., 2004; Morrisey et al., 2006; Krkosek et al., 2007; Diana, 2009). However, there are limited studies on the impact of aquaculture activities in freshwater ecosystems (Arthur et al., 2010; Miranda et al., 2016). The fish diversity in freshwater ecosystems is more sensitive compared to marine ecosystems and the change and modifications in the freshwater are much more striking than in terrestrial ecosystems (Sala et al., 2000; Ekmekçi et al., 2013). The consequences of fish farms on stream fish fauna particularly in terms of change in diversity and abundance have so far not been evaluated quantitatively.

Diversity loss is both a measure of environmental change and an indicator of ecosystem integrity and because of this it is considered one of the most serious ecological problems resulting from human activities (Secretariat of the Convention on Biological Diversity, 2006). In the present study we assessed the impacts of aquaculture activities on the abundance and diversity of native fish communities in Kocabas Stream, Canakkale, Turkey. We conducted field studies to determine species richness and abundance of native fish communities around a fish farm and for a control site situated on the branch of the river without any fish farms. We aimed to develop scientific understanding and gain insights for new management strategies to eliminate potential problems of aquaculture.

\section{Materials and methods}

Kocabas Stream is located in the southwestern part of the Marmara region (Fig. 1). It arises from the northeastern part of the Biga district of Canakkale, results from three main tributaries and reaches the Sea of Marmara south of Karabiga (Tanatmis and Narin, 2004). Mean depth is $50 \mathrm{~cm}$ (DSI, 2000) and total length $80 \mathrm{~km}$ (Kayabasi and Gokceoglu, 2012). This water resource is used as irrigation water for agricultural activities and also drinking water for animals (Yayintas et al., 2007). In addition, aquaculture activities are also carried out in fish farms established on it. 
Sampling was carried out at three stations near a rainbow trout farm built next to Kocabas between August 2015 and July 2016. The aquaculture activity involves taking water from the stream and feeding back wastewater. The annual aquaculture potential of the farm is 60 tons of rainbow trout. One station was selected upstream (Sta 1; $365 \mathrm{~m}, 39^{\circ} 45^{\prime} 37.20^{\prime \prime} \mathrm{N}$ and $27^{\circ}$ $7^{\prime} 35.13^{\prime \prime} \mathrm{E}$ ) and one downstream (Sta 2; $360 \mathrm{~m}, 39^{\circ} 45^{\prime}$ $54.75^{\prime \prime} \mathrm{N}$ and $27^{\circ} 7^{\prime} 33.09^{\prime \prime} \mathrm{E}$ ) from the fish farm. The third station was a control station (Sta $3 ; 357 \mathrm{~m}, 39^{\circ} 45^{\prime} 39.67^{\prime \prime} \mathrm{N}$ and $\left.27^{\circ} 7^{\prime} 18.80^{\prime \prime} \mathrm{E}\right)$ situated on the branch of the stream without fish farms.

At each station the study area was about $1.5 \mathrm{~km}$ long and $2 \mathrm{~m}$ wide. In monthly sampling periods, each station was sampled once using electrofishing with SAMUS $725 \mathrm{G}$. Physicochemical parameters (temperature, $\mathrm{pH}$, dissolved oxygen, electrical conductivity) were measured by a WTW Multiparameter Prob twice at each station; the two values were averaged for analysis. Fish samples were brought to the laboratory maintaining the cold chain. They were identified to species level and the number of species and individuals was recorded.

\section{Data analysis}

To evaluate the impacts of aquaculture on fish communities, the number of species per station (S) was first calculated, followed by the Shannon-Wiener diversity $\left(\mathrm{H}^{\prime}\right)$ and evenness indices, which standardized the sample size in terms of abundance and number of species, in order to establish the relation of the number of species to the total abundance. The relative abundance of each species was calculated with the following formula (Tramer, 1969); $p_{i}=$ total abundance of species $_{i} /$ total abundance of all species.

The Shannon-Wiener Diversity Index $H^{\prime}$ and Evenness $E$ were calculated using (Shannon 1948);

$$
\begin{gathered}
\mathrm{H}^{\prime}=-\Sigma \mathrm{p}_{\mathrm{i}} \ln \mathrm{p}_{\mathrm{i}} \\
\mathrm{E}=\mathrm{H}^{\prime} / \ln (\mathrm{S})
\end{gathered}
$$

Differences between relative abundances of each species caught monthly at the three stations were tested using nonparametric Kruskal-Wallis tests. The pairwise differences among upstream-downstream, upstream-control and downstream-control stations were determined with non-parametric ranked based Mann-Whitney $U$ tests. The spatial variations in diversity and evenness among station were also compared with Kruskal-Wallis tests. Correlations between species abundances among stations were calculated with Spearman's rho. A 0.05 alpha level was used for all tests. Spatial and seasonal differences of physicochemical parameters were tested with two-way ANOVA. The homogeneity of variances of each parameter was tested by Levene's test and non-homogeneous variable were transformed before ANOVA.

\section{Results}

Temperature values ranged between $8.8^{\circ} \mathrm{C}$ (November) and $20.2^{\circ} \mathrm{C}$ (August), $\mathrm{pH}$ values between 6.87 (September) and 8.34 (August), electrical conductivity values between $134 \mu \mathrm{Scm}^{-1}$ (April) and $289.5 \mu \mathrm{Scm}^{-1}$ (March), and dissolved oxygen values varied between $6.9 \mathrm{mgL}^{-1}$ (October) and $10.72 \mathrm{mgL}^{-1}$ (March). Dissolved oxygen values were highest during winter months when temperatures were generally lowest. These measurements are compatible with the literature (Hacıglu and Dülger, 2009; Akbulut et al., 2014).We recorded four freshwater fish species during field sampling; sea trout Salmo cf. macrostigma (Dumeril 1958), minnow Phoxinus phoxinus (Linnaeus 1758), Marmara barbel Barbus oligolepis (Battalgil 1941) and European chub Squalius cii (Richardson 1857). Averaged across months, the relative abundance of $P$. phoxinus was highest with $46.3 \%$, followed by $S$. $c f$. macrostigma with $22.3 \%$, S. cii $16.7 \%$ and B. oligolepis $14.7 \%$. Thus $P$. phoxinus was the dominant species in the stream.

Although there was no difference with regard to relative abundance of $S$. cf. macrostigma $\left(x^{2}=2.4 ; \mathrm{df}=2 ; P>0.05\right)$ among stations, the relative abundances of the other three species differed significantly among stations $\left(x_{\text {P. phoxinus }}^{2}=6.6\right.$; $\mathrm{df}=2 ; \mathrm{P}_{P \text {. phoxinus }}<0.05 ; x^{2}{ }_{B \text {. oligolepis }}=11.1 ; \mathrm{df}=2 ; \mathrm{P}_{B}$. oligolepis $<0.05 ; x^{2}$ S. cii $\left.=8.7 ; \mathrm{df}=2 ; \mathrm{P}_{\text {S. cii }}<0.05\right)$. The relative abundances of $P$. phoxinus at the upstream and control stations were higher compared to the downstream station in the Kocabas Stream; both pairwise comparisons were statistically significant (upstream-downstream: $Z=2.3 ; P<0.05$; downstream-control: $Z=2.2 ; P<0.05)$. In contrast, the relative abundance of $B$. oligolepis was higher at the downstream station compared to the other two stations; both pairwise comparisons were significant (upstream-control: $Z=2.4$, $P<0.05$; downstream-control: $\mathrm{Z}=3.1, P<0.05)$. $S$. cii was also more abundant at the downstream station; only upstream and downstream stations were significantly different $(Z=2.9$; $P<0.05)$.

The monthly species compositions are shown in Figure 2. While $P$. phoxinus was the dominant species almost in all months at the upstream and control stations, at the downstream station the dominance this species was limited to December to June (Fig. 2). There were two peaks in spring and fall in the abundance of $P$. phoxinus at the upstream and control stations. The fall peak of this species was weak at the downstream station. S. cf. macrostigma was not or little encountered between December and March at all stations. At the upstream station, the relative abundance of $S$. cf. macrostigma reached $40 \%$ in November and December and was much lower in the other months. At the downstream station, the highest relative abundance was found in August (nearly 60\%). At the control station the highest relative abundances were found in summer and autumn. $B$. oligolepis was mainly caught at the upstream and downstream stations. The relative abundance of this species was higher in summer and early autumn (September) at both stations. The last species, $S$. cii's, was relatively rare at the upstream station and not caught during winter and spring sampling periods. Its relative abundance at the downstream and control station was higher compared to the upstream station (Fig. 2).

Shannon-Wiener diversity and Evenness were not statistically different between stations $(P>0.05)$. They both varied seasonally, with lowest values found in February, March and April at all stations (Fig. 3). This decline was particularly pronounced at the first station and the control station was the 

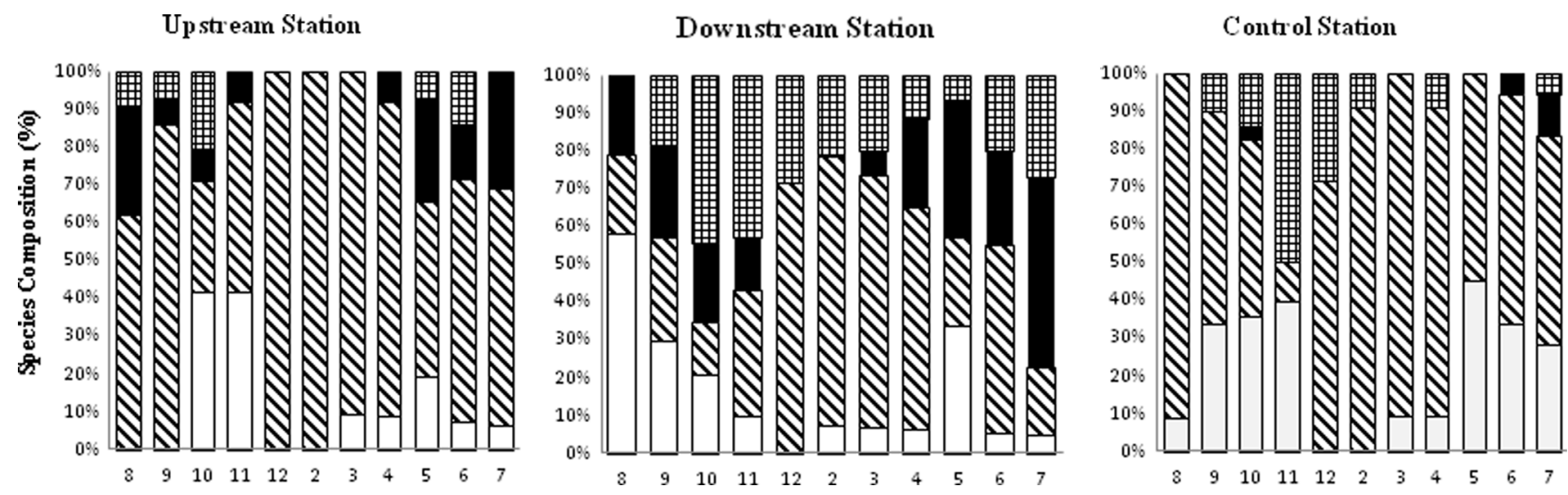

Months

Fig. 2. Monthly species composition at three sampling stations on Kocabas Stream near a fish farm (White: $S$. $c f$. macrostigma, Striped: $P$. phoxinus, Black: B. oligolepis, Squared: S. cii).
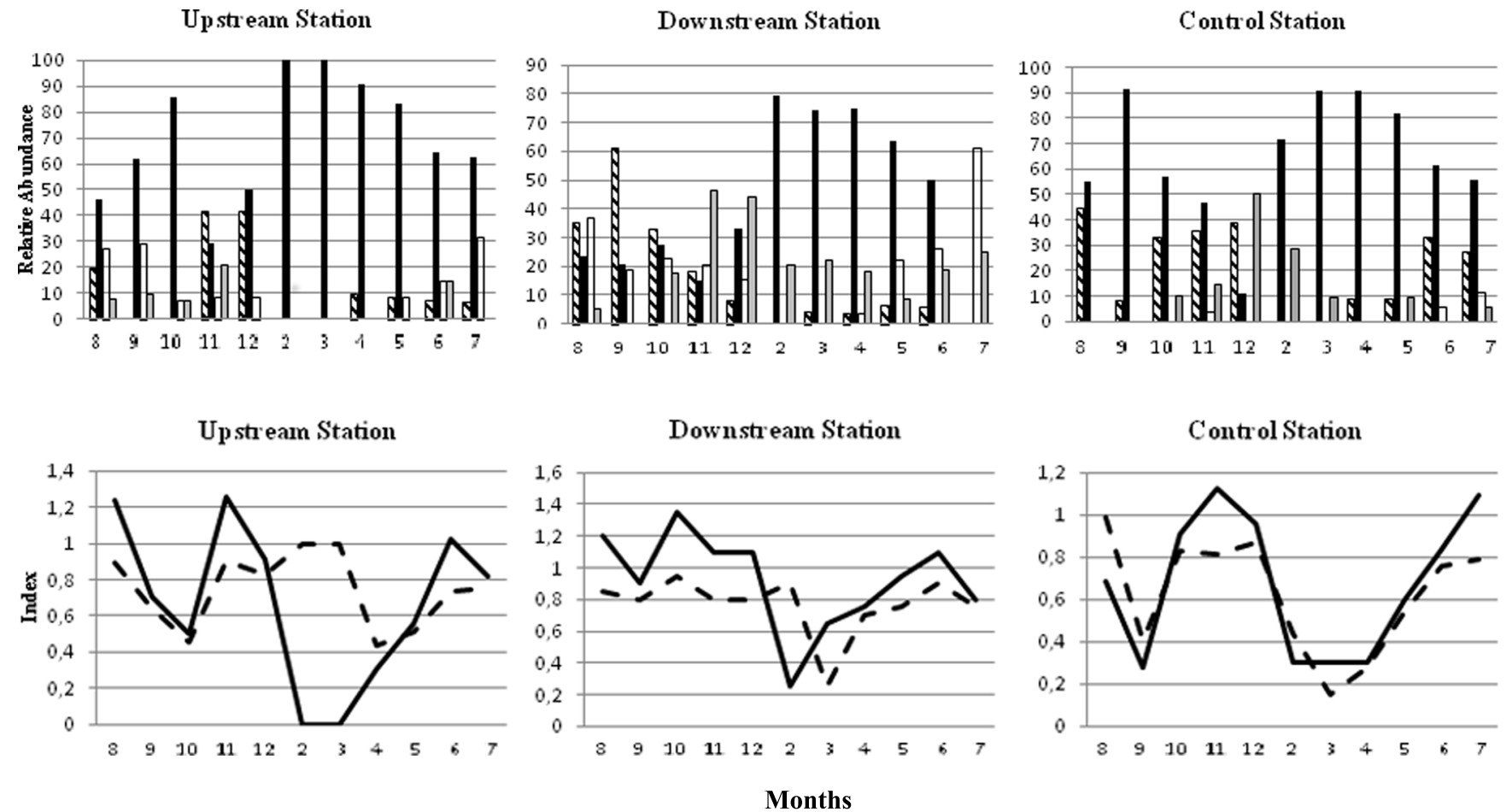

Fig. 3. Shannon-Wiener biodiversity Index $\left(\mathrm{H}^{\prime}\right)$ and Evenness (E) values for species collected monthly from upper, lower and control sites. Continuous line H'; dotted line: E.

least affected. In general, indices for the upstream and control stations were more similar.

Monthly variations in relative abundance of $P$. phoxinus were significantly negatively correlated with the other three species at the station upstream from the fish farm (Table 1). At the control station they were only significantly negatively correlated with $S$. cf. macrostigma and no correlations were found for the downstream station. None of the other species were correlated at any of the stations.

Water quality parameters measured in each sampling area are presented in Figure 4. Temperature and electrical conductivity did not significantly differ among stations
$($ Ftemp $=0.09, \mathrm{df}=2, P>0.05 ; \mathrm{Fec}=0.3, \mathrm{df}=2, P>0.05)$, while seasonal differences were statistically significant $(\mathrm{Ft}=$ 29.5, $\mathrm{df}=3, P<0.05 ; \mathrm{Fec}=8.6, \mathrm{df}=3, P<0.05)$. $\mathrm{PH}$ and dissolved oxygen values were also similar $(\mathrm{Fph}=0.2, \mathrm{df}=2$, $P>0.05 ; \mathrm{Fdo}=0.3, \mathrm{df}=2, P>0.05)$ and differed seasonally $(\mathrm{Fph}=0.7, \mathrm{df}=3, P>0.05 ; \mathrm{Fdo}=0.4, \mathrm{df}=3, P>0.05)$.

\section{Discussion}

Studying fish survival and mobility contributes to understanding the long-term effects of environmental or 
Table 1. Correlation test results (Spearman's rho) for monthly relative species abundances at three sampling stations on Kocabas Stream near a fish farm ( $n=11$ months).

\begin{tabular}{llll}
\hline & upstream (Sta 1) & downstream (Sta 2) & control (Sta 3) \\
\hline S.cf. macrostigma -P. phoxinus & $-\mathbf{0 . 6 7}{ }^{*}$ & -0.55 & $-\mathbf{0 . 8 4}$ \\
S.cf. macrostigma -B. oligolepis & 0.16 & 0.14 & 0.25 \\
S.cf. macrostigma -S.cii & 0.16 & -0.22 & 0.04 \\
phoxinus- B. oligolepis & $-\mathbf{0 . 7 2}{ }^{*}$ & -0.45 & -0.36 \\
P phoxinus- S.cii & $-\mathbf{0 . 5 9}{ }^{*}$ & -0.24 & -0.46 \\
B.oligolepis- S.cii & 0.42 & -0.12 & -0.15 \\
\hline
\end{tabular}

${ }^{*} p$-value $<0.05$
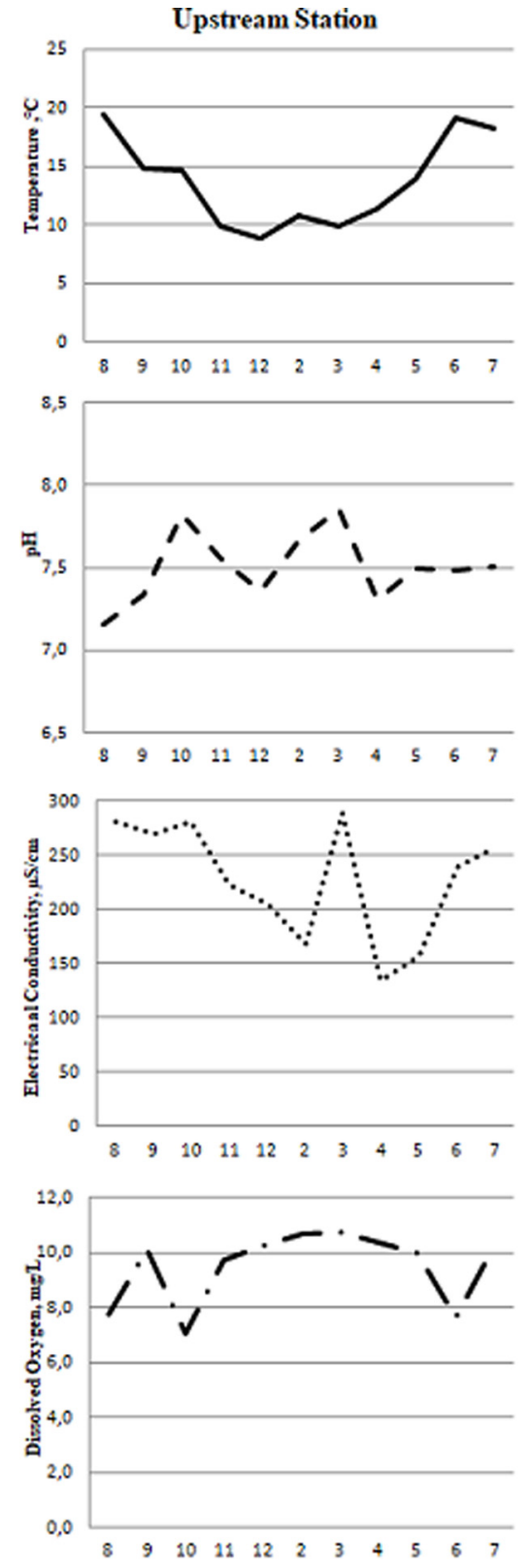

Downstream Station
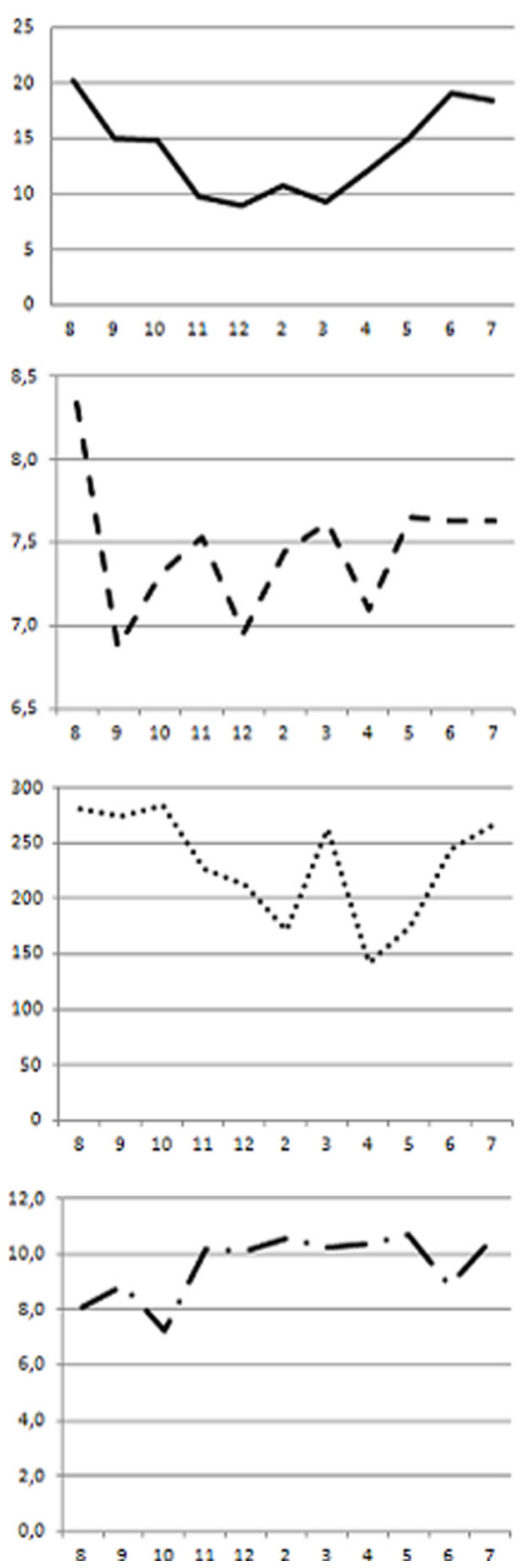

Control Station
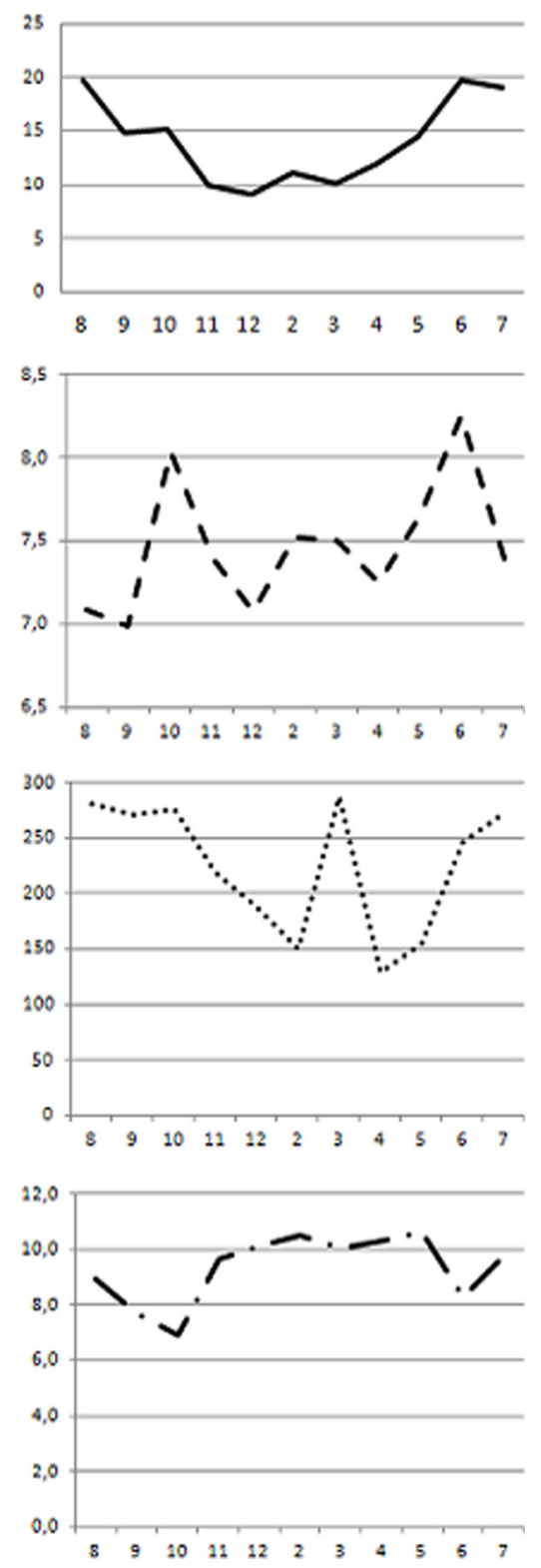

Months

Fig. 4. Physicochemical parameters measured at the three sampling stations on Kocabas Stream near a fish farm. 
anthropogenic factors and habitat conditions (Karr et al., 1986; Stephens and Farris 2004). As shown in this study, the Kocabas Stream provides suitable habitats for four fish species. For the upper trout and grayling zone, the presence of these species is an indicator of stream environmental conditions. The results of the present study on the potential effects of a rainbow trout farm on native fauna indicated no large alterations, especially with respect to the diversity of native species. However, the results suggested potential variations in the composition and relative abundance of native fish species, possibly as a consequence of the impact of the farm.

Published studies have focused on the adverse effects of fish farms such as blocking migratory routes and disturbance of ecosystem functioning by habitat modifications (Agostinho et al., 2005, 2007, 2008; Gubiani et al., 2007; JúlioJúnior et al., 2009). In this study, the fish farm did not present any physical obstacle to migration. Therefore, we studied the potential effects on diversity and its seasonal changes.

The study area was located in the trout and grayling zones (for P. phoxinus) of the Kocabas Stream. B. oligolepis and S. cii were found at all three sampled stations. Both species are common along the Kocabas stream (Çiçek et al., 2015) but their higher relative abundance in the trout and grayling zones (downstream station) might have been caused by a farm effect. Artificial food components scattered from the farm might be rich in fish meal and thus provide direct food for native fish species downstream from the farm. On the other hand, these scattered food components might be a source of high nutrient input throughout the stream food web and result in rich macroinvertebrates as live food, thus representing an indirect food input. Both explanations are important, particularly for the trout and grayling zone resident fish species $c f$. macrostigma and P. phoxinus. A detailed study is suggested on the feeding ecology of these species.

The negative correlations found between freshwater fish species relative abundances might be explained by predatorprey relationships (Cooper et al., 1990; Borgstrøm et al., 1996, 2010; Museth et al., 2007, 2010). P. phoxinus is a small fish species and might be potential food for the other three species. Some records exist for this species in sea trout diet (Museth et al., 2010). There might have been a shift in the diet of sea trout and other predatory fishes at the downstream station caused by changes in the availability of food resources. The results indicated that there might be competition between $S$. $c f$. macrostigma, B. oligolepis and S. cii. However, B. oligolepis might have had more success in collecting prey items compared to the other species and S. cf. macrostigma and $S$. cii might have shifted their diet from P. phoxinus to other food items. This hypothesis needs to be investigated further.

\section{Conclusion}

Aquaculture develops in many regions around the world. The results and methods of this study provide baseline information on the relative abundance and diversity of fish associated with aquaculture sites. In the study the fish farm was not an obstacle for migration of any fish species. We found that the aquaculture activity might explain higher relative abundances of some species. This finding is in accordance with Dempster et al., 2004; Machias et al., 2004; Neofitou et al., 2010; Briones et al., 2016. However, this higher relative abundance favored downstream fish species rather than $S$. $c f$. macrostigma. S. cf. macrostigma is one of the most important economic fish species in up streams and population dynamics of this species might have been affected by the aquaculture activity. This hypothesis needs to be further investigated.

Acknowledgement. The authors would like to acknowledge support by COMU- BAP (412 coded Project) and the Ministry of Forestry and Water Management, Nature Protection and National Park General Directorate, Çanakkale Regional District. We also thank İlker BAKAÇ for helping with field sampling. This study was completed with the permits COMÜ Animal Ethics Committee (30.07.2015/B.30.2. CAU.0.05.06-050.04-65), Ministry of Forestry and Water Management (02.01.2017/49978340-499-1621) and Ministry of Food, Agriculture and Livestock (06.10.2015/67852565140.03.03-2556).

\section{References}

Agostinho AA, Thomaz SM, Gomes LC. 2005. Conservation of the biodiversity of Brazil's inland waters. Conserv Biol 19: 646-652.

Agostinho AA, Thomaz SM, Gomes LC, Baltar SLSMA. 2007. Influence of the macrophyte Eichhorniaazurea on fish assemblage of the Upper Paraná River floodplain (Brazil). Aquat Ecol 41: 611-619.

Agostinho AA, Pelicice FM, Gomes LC. 2008. Dams and the fish fauna of the Neotropical Region: impacts and management related to diversity and fisheries. Braz J Biol 68: 1119-1132.

Akbulut M, Selvi K, Kaya H, Duysak M, Akçay F, Çelik ES. 2014, Use of oxidative stress biomarkers in three Crustacean species for the assessment of water pollution in Kocabas Stream (Çanakkale, Turkey). Mar Sci Tech Bull 3: 27-32.

Allan JD, Flecker AS. 1993. Biodiversity conservation in running waters. Bioscience 43: 32-43.

Arthur RI, Lorenzen K, Homekingkeo P, Sidavong K, Sengvilaikham B, Garaway CJ. 2010 Assessing impacts of introduced aquaculture species on native fish communities: Nile tilapia and major carps in SE Asian freshwaters. Aquaculture 299: 81-88.

Aubin J. 2006. Characterisation of the environmental impact of a turbot (Scophthalmusmaximus) re-circulating production system using life cycle assessment. Aquaculture 261: 1259-1268.

Beveridge MCM., A quantitative and qualitative assessment of wastes from aquatic animal production. Aquaculture and water quality. The World Aquaculture Society, 1990

Boesch DF, Burroughs RH, Baker JE, Mason RP, Rowe CL, Siefert RL. Marine Pollution in the United States: Significant Accomplishments, Future Challenges. Pew Oceans Commission, Arlington, Virginia, 2001

Borgstrøm R, Brittain JE, Hasle K, Skjølås S, Dokk JG, 1996. Reduced recruitment in brown trout Salmotrutta, the role of interactions with the minnow, Phoxinusphoxinus. Nordic J Freshw Res 72: 30-38.

Borgstrøm R, Museth J, Brittain JE. 2010, Brown trout (Salmotrutta) in the lake, ØvreHeimdalsvatn; long-term changes in population dynamics due to exploitation and the invasive species, European minnow (Phoxinusphoxinus). Hydrobiologia 642: 81-91.

Briones JCA, Papa RDS, Cauyan GA, Mendoza N, Okuda N. 2016. Fish diversity and trophic interactions in Lake Sampaloc (Luzon Is., Philippines). Trop Ecol 57 
Carss DN. 1990 Concentrations of wild and escaped fishes immediately adjacent to fish farm cages. Aquaculture 90: 29-40.

Çiçek E, Birecikligil SS, Fricke R, 2015. Freshwater fishes of Turkey: a revised and updated annotated checklist. Biharean Biol 9: 141157.

Cooper SD, Walde SJ, Peckarsky BL. 1990. Prey exchange rates and the impact of predators on prey populations in streams. Ecology 71: $1503-1514$.

Currie DJ. 1991. Energy and large-scale patterns of animal- and plantspecies richness. Am Nat 137: 27-49.

Demir N, Kırkagaç, MU, Pulatsü S, Bekcan S. 2001. Influence of trout cage culture on water quality, plankton and benthos anatolian dam lake. Israeli Aquacu-Bamidgeh 53: 115-127.

Dempster T, Sanchez-Jerez P, Bayle-Sempere J, Kingsford M. 2004, Extensive Aggregations of Wild Fish at Coastal Sea-cage Fish Farms. Hydrobiologica 525: 245-248.

Dempster T, Sanchez-Jerez P, Bayle-Sempere JT, Giménez-Casalduero F, Valle C. 2002. Attraction of Wild Fish to Sea cage Fish Farms in the South-Western Mediterranean Sea: Spatial and Shortterm Temporal Variability. Marine Ecol 242: 237-252.

Diana JS. 2009. Aquaculture production and biodiversity conservation. Bioscience 59: 27-38.

DSI, Annual flow observation report, 25th Region Directory, Balıkesir-TURKEY, 2000

Dudgeon D, Arthington AH, Gessner MO, Kawabata ZI, Knowler DJ, Lévêque C, Naiman RJ, Prieur-Richard AH, Soto D, Stiassny MLJ, Sullivan CA. 2006. Freshwater biodiversity: importance, threats, status and conservation challenges. Biol Rev 81: 163-182.

Ekmekçi FG, Kırankaya ŞG, Gençoglu L, Yogurtçuoglu B. 2013. Türkiyeİçsularındakiİsti-

lacıBalıklarınGüncelDurumuveİstilanınEtkilerininDegerlendirilmesi. Ístanbul Üniversitesi Su ÜrünleriDergisi 28: 105-140.

Findlay RH, Watling L. Prediction of Benthic Impact for Salmon NetPens Based on the Balance of Benthic Oxygen Supply and Demand. Marine Sciences Faculty Scholarship. 98, 1997

Geist J. 2011 Integrative freshwater ecology and biodiversity conservation. Ecol Indi 11: 1507-1516.

Goldberg RJ, Elliott MS, Naylor RL. Marine Aquaculture in the United States: Environmental Impacts and Policy Options. Pew Oceans Commission, Arlington, Virginia, 2001

Gubiani EA, Gomes LC, Agostinho AA, Okada EK. 2007. Persistence of fish populations in the upper Paraná River: effects of water regulation by dams. Ecol Freshw Fish 16: 191-197.

Hacioglu N, Dülger B. 2009. Monthly Variation of Some Physicochemical and Microbiological Parameters in Biga Stream (Biga, Canakkale, Turkey). Afr J Biotechnol 8

Hargrave BT, Phillips GA, Doucette LI, White MJ, Milligan TG, Wildish DJ, Cranston RE. 1997 Assessing benthic impacts of organic enrichment from marine aquaculture. Water Air Soil Pollut 99: 641-650.

Holmer M. Impacts of Aquaculture on Surrounding Sediments: Generation of Organic rich Sediments. in: De Pauw N., Joyce J. (Eds.), Aquaculture and the Environment, Aquaculture Society Special Publication 16, 155-175, 1991.

Iwama G.K. 1991. Interactions Between Aquaculture and the Environment. Crit Rev Environ Control 21: 177-216.

JúlioJúnior HF, Dei Tós C, Agostinho AA, Pavanelli CS. 2009. A massive invasion of fish species after eliminating a natural barrier in the upper Rio Paraná basin. Neotropical Ichthyol 7:709-718.

Karr JR, Fausch KD, Angermeier PL, Yant PR, Schlosser IJ. Assessing biological integrity in running waters: a method and its rational. Illinois Natural History Survey, Special Publication, Champaign, IL, 1986
Kayabasi A, Gokceoglu C. 2012. Coal Mining under Difficult Geological Conditions: the Can Lignite Open Pit (Canakkale, Turkey). Eng Geol 135: 66-82.

Krebs CJ. Ecology-The Experimental Analysis of Distribution and Abundance. Pearson Benjamin Cummings, San Francisco, USA, 2009

Krkosek M, Ford J.S, Morton A, Lele S, Myers RA, Lewis MA. 2007 Declining wild salmon populations in relation to parasites from farm salmon. Science 318: 1772-1775.

La Rosa T, Mirto S, Mazzola A, Danovaro R. 2001. Differential responses of benthic microbes and meiofauna to fish-farm disturbance in coastal sediments. Environ Pollut 112: 427-434.

Machias A, Karakassis I, Labropoulou M, Somarakis S, Papadopoulou KN, Papaconstantinou C. 2004. Changes in Wild Fish Assemblages after the Establishment of a Fish Farming Zone in an Oligotrophic Marine Ecosystem. Estuar Coast Shelf Sci 60: 771779.

Malmquist B, Rundle S. 2002. Threats to running water ecosystems in the world. Environ Conserv 29: 134-153.

Maury-Brachet R, Rochard E, Durrieu G, Boudou A. 2008. The storm of the century (December 1999) and the accidental escape of Siberian sturgeons (Acepenserbaerii) into the gironde estuary (Southwest France). An original approach for metal contamination. Environ Sci Pollut Res Int 15: 89-94.

Miranda TO, Lima HS, Galon B, Veronez AC, Moretti MS, Roper JJ, Gomes LC. 2016. Changes in water quality and the phytoplankton community associated with tilapia cage farming in tropical lakes. Aquat Living Res 29: 403.

Mirto S, La Rosa T, Gambi C, Danovaro R, Mazzola A. 2002. Nematode community response to fish-farm impact in the western Mediterranean. Environ Pollut 116: 203-214.

Morrisey DJ, Cole RG, Davey NK, Handley SJ, Bradley A, Brown SN, Madarasz AL. 2006 Abundance and diversity of fish museel farms in New Zealand. Aquaculture 252: 277-288.

Museth J, Borgstrøm R, Brittain JE. 2010, Diet overlap between introduced European minnow (Phoxinusphoxinus) and young brown trout (Salmotrutta) in the lake, ØvreHeimdalsvatn: a result of abundant resources or forced niche overlap?. Hydrobiologia 642: 93-100.

Museth J, Hesthagen T, Sandlund OT, Thorstad EB, Ugedal O. 2007. The history of the minnow Phoxinusphoxinus (L.) in Norway: from harmless species to pest. J Fish Biol 71 (Suppl D): 184-195.

Naiman RJ, Turner MG. 2000 A future perspective on North America's freshwater ecosystems. Ecol Appl 10: 958-970.

Naylor RL, Goldburg RJ, Primavera JH, Kautsky N, Beveridge MCM, Clay J, Folke C, Lubchenco J, Mooney H, Troell M. 2000. Effect of Aquaculture on World Fish Supplies. Nature 405: 10171024.

Neofitou N, Vafidis D, Klaoudatos S, 2010. Spatial and temporal effects of fish farming on benthic community structure in a semienclosed gulf of the Eastern Mediterranean. Aquac Environ Interact 1: 95-105.

Pearson TH, Black KD. The environmental impacts of marine fish cage culture. in: Black K.D. (Ed.), Environmental Impacts of Aquaculture. Sheffield Academic Press, Sheffield, 2000 pp. 1-31.

Pergent G, Mendez S, Pergent-Martini C, Pasqualini V. 1999. Preliminary data on the impact of fish farming facilities on Posidonia oceanic meadows in the Mediterranean. Ocean Acta 22: 95-107.

Postel S, Richter B. Rivers for life: managing water for people and nature. Island Press, Washington, USA, 2003

Sala OE, Chapin III FS, Armesto JJ, Berlow E, Bloomfield J, Dirzo R, Huber-Sanwald E, Huenneke LF, Jackson RB, Kinzig A, Leemans 
R, Lodge DM, Mooney HA, Oesterheld M, Poff NL, Sykes MT, Walker BH, Walker M, Wall DH. 2000. Global biodiversity scenarios for the year 2100. Science 287: 1770-1774.

Secretariat of the Convention on Biological Diversity. Global Biodiversity Outlook 2, Montreal, 2006

Shannon CE. 1948. A mathematical theory of communication, Part I, Part II. Bell Syst Tech J 27: 623-656.

Stephens WW, Farris JL. 2004. Instream community assessment of aquaculture effluents. Aquaculture 231: 149-162.

Stickney RR. Principles of Aquaculture. Wiley, New York, 1994

Stokstad E. 2002. Engineered fish: friend or foe of the environment?. Science 297: 1797-1799.

Tanatmıs M, Narin NÖ. 2004. Gönen (Balıkesir) veBiga (Çanakkale) Çayları'nınEphemeroptera (Insecta) Limnofaunası. BAÜ Fen Bil Enst. Dergisi 6: 16-25.

Tramer EJ. 1969. Bird species diversity: components of Shannon's formula. Ecology 50: 927-929.
Troell M, Norberg J. 1998 Modelling Output and Retention of Suspended Solids in an Integrated Salmon-Mussel Culture. Ecol Mod 110: 65-77.

Ward JV, Tockner K. 2001. Biodiversity: towards a unifying theme for river ecology. Freshwater Biol 46: 807-819.

Wilding TA, Cromey CJ, Nickell TD, Hughes DJ. 2012. Salmon Farm Impacts on Muddy-Sediment Megabenthic Assemblages on the West Coast of Scotland. Aquac Environ Interact 2: $145-156$.

Willig MR, Kaufman DM, Stevens R.D. 2003. Latitudinal gradients of biodiversity: pattern, process, scale, and synthesis. Annu Rev Ecol Evol Syst 34: 273-309.

Yayintas ÖT, Yilmaz S, Türkoĝlu M, Şolakoĝlu FA, Şakir F. 2007. Seasonal variation of some heavy metal pollution with environmental and microbiological parameters in sub-basin of Kocabas Stream (Biga, Canakkale, Turkey) by ICP-AES. Environ monit assess 134: 321-331.

Cite this article as: Ertürk Gürkan S, Yalçin Özdilek Ş. 2018. The effects of aquaculture activities on species composition and diversity of native freshwater fish populations. Aquat. Living Resour. 31: 17 